Accepted author's manuscript. Published in final edited form as: Journal of Cancer and Survivorship 2020 (in press). Publisher DOI: 10.1007/s11764-020-00920-9

\title{
Transition from pediatric to adult follow-up care in childhood cancer survivors - a systematic review
}

Maria Otth ${ }^{1,2 *}$, Sibylle Denzler ${ }^{1 *}$, Christa Koenig $^{3}$, Henrik Koehler ${ }^{4}$, Katrin Scheinemann $^{1,5,6}$

${ }^{1}$ Division of Oncology-Hematology, Department of Pediatrics, Kantonsspital Aarau, Switzerland

${ }^{2}$ Childhood Cancer Research Group, Institute of Social and Preventive Medicine, University of Bern, Bern, Switzerland

${ }^{3}$ Division of Pediatric Hematology/ Oncology, Department of Pediatrics, Inselspital, Bern University Hospital, University of Bern, Switzerland

${ }^{4}$ Department of Pediatrics, Kantonsspital Aarau, Switzerland

${ }^{5}$ Division of Hematology/Oncology, University Children's Hospital Basel (UKBB) and University of Basel, Switzerland

${ }^{6}$ Department of Pediatrics, McMaster Children's Hospital and McMaster University, Hamilton, Canada

* shared first authorship

Corresponding Author: Maria Otth MD, Division of Oncology - Hematology, Department of Pediatrics, Kantonsspital Aarau, Switzerland. Phone: 00416283841 41. E-mail: maria.otth@ksa.ch

\section{Acknowledgement}

We would like to thank the librarians Beatrice Minder and Doris Kopp, University of Bern, for their support.

Funding: This publication was supported by Swiss Cancer Research (HSR-4359-11-2017). 


\begin{abstract}
Purpose: The successful transition of childhood cancer survivors from pediatric- to adult-focused long-term follow-up care is crucial and can be a critical period. Knowledge of current transition practices, especially regarding barriers and facilitators perceived by survivors and health care professionals, is important to develop sustainable transition processes and implement them into daily clinical practice. We performed a systematic review with the aim of assessing transition practices, readiness tools, and barriers and facilitators.
\end{abstract}

Methods: We searched three databases (PubMed, Embase/Ovid, CINAHL) and included studies published between January 2000 and January 2020. We performed this review according to the PRISMA guidelines and registered the study protocol on PROSPERO; two reviewers independently extracted the content of the included studies.

Results: We included 26 studies: six studies described current transition practices, six assessed transition readiness tools, and 15 assessed barriers and facilitators to transition.

Conclusion: The current literature describing transition practices is limited and overlooks adherence to followup care as a surrogate marker of transition success. However, the literature provides deep insight into barriers and facilitators to transition and theoretical considerations for the assessment of transition readiness. We showed that knowledge and education are key facilitators to transition that should be integrated into transition practices tailored to the individual needs of each survivor and the possibilities and limitations of each country's health care system.

Implications for Cancer Survivors: The current knowledge on barriers and facilitators on transition should be implemented in clinical practice to support sustainable transition processes.

\title{
Keywords
}

Childhood cancer survivors; transition; long-term follow-up care; adolescents and young adults 


\section{Background}

Most children and adolescents diagnosed with cancer will become long-term survivors. There is a broad international consensus that most of these childhood cancer survivors (CCSs) need life-long follow-up care, as the majority experience one or more late effects due to the cancer treatment received $[1,2]$. The goal of longterm follow-up (LTFU) care is to reduce the burden of late effects among CCSs by prevention, early detection or adequate treatment, which ultimately leads to an overall improvement in the CCSs' quality of life. Today, many adolescent and adult CCSs discontinue regular follow-up care once they have left the pediatric setting, with a steady drop off over time after treatment completion [3-5]. The change in LTFU care from the pediatric to adult setting is referred to as a transition, and it has been generally defined as an "active, planned, coordinated, comprehensive, multidisciplinary process to enable childhood and adolescent cancer survivors to effectively and harmoniously transfer from child-centered to adult-oriented healthcare systems" [6]. The transition process itself is closely linked to the following LTFU care models, which can be implemented in different ways [7-10]. In the cancer-center-based model, CCSs either transition directly from pediatric to adult oncology or internal medicine as a one-step process or undergo a stepwise transition carried out by a mixed team of pediatric and adult health care professionals (HCPs) before finally switching to adult care. Variants of this model involve specialized LTFU clinics with multidisciplinary teams that provide life-long LTFU care. In primary care models, CCSs transition to general practitioners with adult specialist consultations as needed (e.g., cardiologist). In shared-care models, LTFU care is provided by primary care physicians in collaboration with a cancer center.

Many obstacles can hinder the practical implementation of these transition processes, such as barriers at the levels of the survivor, family, providers and health care system. The ideal transition would overcome barriers at all levels and would take facilitators and needs into account.

Many publications have reported on different LTFU care models, but the literature on the actual transition process, including barriers and facilitators and measures of the success of different transition processes, is scarce. This systematic review aims to close this knowledge gap. We aim to provide comprehensive insight into current transition practices for CCSs from pediatric to adult LTFU care; to describe tools used in transitional care; to summarize barriers and facilitators to the transition process from CCSs', parents' and health care professionals' points of view; and to assess loss to follow-up in relation to different transition practices. 


\section{Methods}

We performed this review according to the PRISMA guidelines for reporting systematic reviews and metaanalyses [11] and registered the protocol on PROSPERO (ID: CRD42019132786).

\subsection{Literature search}

We conducted a systematic literature search with the aid of an experienced information specialist in February 2020 and searched three databases (PubMed, Embase/Ovid, CINAHL) (Supplemental S1). We restricted the search to studies published from January 2000 to January 2020 and studies available in English or German. We built the search strategy for all three databases around four concepts. We identified MeSH terms and free text words for each concept, which we finally combined. For the population of interest, we included the concepts of "cancer" (including different types of childhood cancers), "children and adolescents" and "survivors". For the outcome, we chose terms related to "transition". In addition to the three bibliographic databases, we searched Google Scholar in English ("childhood cancer | childhood cancer survivor AND aftercare | follow-up") and German ("Kinderkrebs transition| Nachsorge”). For each review article identified with our search, we screened the reference list for relevant original articles.

\subsection{Inclusion and exclusion criteria}

To be included in this review, the studies had to report on cancer survivors who were diagnosed during childhood or adolescence, who completed their cancer treatment and were in the process of transition or had finished transition when included in the respective study. The term "transition" in the context of this review only refers to the change from pediatric- to adult-focused LTFU care. For a study cohort to be considered "children or adolescents", at least $75 \%$ of participants had to be aged less than 18 years at the time of the cancer diagnosis. We excluded studies that did not fulfill the inclusion criteria, case reports, case series $(\mathrm{n} \leq 14)$, commentaries, editorial letters, poster abstracts and review articles.

\subsection{Outcomes}

The primary outcomes of this review were current transition practices and care needs during transition. The assessment of current transition practices also included information on transition readiness tools, as these tools can be part of transition practices. Care needs included barriers and facilitators to transition and could be 
reported by CSSs, parents or health care professionals. Loss to follow-up during transition was assessed as a secondary outcome, as this might be an indirect marker of whether a transition practice is successful.

\subsection{Data extraction and quality assessment}

Two reviewers (MO and SD) screened all titles and abstracts separately and excluded those not fulfilling the inclusion criteria. Any disagreements were discussed and resolved by a third reviewer (KS). The same reviewers (MO and SD) independently checked all retrieved full texts for adherence. In case of disagreement or doubts, a third reviewer (KS) was approached. Data from the eligible studies were extracted to a standard sheet including the first author, year of publication, CCSs' age at diagnosis and time of the study, follow-up time, sample size, role of the study participants (survivor, parent, or health care professional), study design, type of transition model, barriers and facilitators to transition, perception of transition, and loss to follow-up. To summarize barriers and facilitators, we first listed all of them in their original wording and subsequently grouped them based on content. We assessed the quality, relevance and reliability of each included study on barriers and facilitators by using the appropriate critical appraisal tool from the Joanna Briggs Institute [12], including the checklists for qualitative research and cross-sectional studies (Supplemental S2). Since these tools do not use any categorization, we made a classification with three categories. If all criteria of the respective checklist were fulfilled, we assigned the study to "Quality 1". If a qualitative study did not include a statement locating the researcher culturally and theoretically or a summary of the influence of the researcher on the research and vice versa, we assigned the study to "Quality 2". If a cross-sectional study did not assess confounders or did not clearly state how confounders were selected and used in the analysis, the study was assigned to "Quality 2". If an additional point from the checklist for both types of studies was insufficiently covered, we assigned the study to "Quality 3".

\section{Results}

\subsection{Literature search result}

Our search identified 6156 records. After screening the titles and abstracts, we excluded 5951 records. Finally, we included 26 studies, one of which reported on two of the assessed outcomes [13] (Supplemental 3). 


\subsection{Study findings}

\subsubsection{Current transition practices}

We identified six studies describing the transition process in detail, one of which described two processes

(Table 1). Three studies discussed transition processes that ultimately reflected shared-care models including the involvement of general practitioners [14-16]. Three studies described the transition to adult LTFU clinics $[13,17,18]$, and one of these studies additionally discussed the transition to LTFU care provided by a combination of pediatric and adult HCPs [13]. We included six studies outlining five different tools, such as scales, questionnaires, and models, used to assess transition readiness among CCSs (Table 2) [19-24]. Although the applicability of four of the tools has been validated, these tools have not yet been implemented in daily clinical practice [19-21, 24].

\subsubsection{Barriers and facilitators}

Fifteen studies reported on barriers and facilitators encountered when CCSs transitioned from pediatric to adult LTFU care (Table 3). Seven studies included survivors' perspectives [13, 25-30], five included HCPs' perspectives [31-35], two included survivors' and parents' perspectives [36, 37], and one included survivors', parents', and HCPs' perspectives [38]. The term "HCP" was used to refer to professionals from different disciplines, such as pediatric oncologists, primary care physicians, health care practitioners, nurses, nurse practitioners, psychologists, and social workers. Overall, 523 survivors, 48 parents and 523 HCPs participated in these 15 studies. After the systematic collection of all mentioned barriers and facilitators, we grouped the barriers and facilitators into eight categories (Table 4):

1. CCSs' self-management skills, including knowledge, education and empowerment

2. Social environment, including family, friends, and peers

3. CCSs' personal feelings and emotions

4. Pediatric setting

5. Adult setting

6. Financial issues and insurance

7. Communication

8. Structural circumstances including organization of transition

Barriers and facilitators in the "CCSs" self-management skills" category were the most frequently reported. Certain factors, such as fear and anxiety, were reported to act as facilitators for some CCSs and as barriers for 
other CCSs. Fear of cancer relapse could motivate one CCS to attend LTFU care but hinder another CCS from doing so. The impact of family, and especially parents, was mentioned in a similar way; while some CCSs wanted to gain independence in the process of transition, others needed their families' support even as young adults.

\subsubsection{Impact of transition programs on loss-to follow-up}

We could not identify any study that evaluated the transition process and its success longitudinally through an assessment of the proportion of CCSs not successfully transitioned and lost to follow-up as a surrogate marker.

\section{Discussion}

\subsection{Transition practices and barriers and facilitators to transition}

Our review shows that the literature describing transition processes is limited and lacks evaluation of transition success. In contrast, the literature provides deep insight into barriers and facilitators to transition and theoretical considerations for the assessment of transition readiness.

Transition is crucial not only for the CCS population but also for adolescents and young adults with other chronic diseases, such as inflammatory bowel disease [39], diabetes [40, 41] and rheumatic diseases [42]. One study including adolescents with type 1 diabetes compared an unstructured transition to adult care with a structured transfer planned together with adult physicians. The authors showed that adolescents with a structured transfer had higher clinical attendance, lower HbA1c and a more positive opinion of the transition process after one year than those with an unstructured transition [40]. The structured transfer included a transition coordinator, clear explanations about the process and clinical implications at each visit, and two joint consultations with pediatric and adult endocrinologists. In accordance, the factors "transition coordinator" and "knowing the adult setting before actual transfer" were frequently reported facilitators from the CCSs' perspective. "Clear explanation/education" was also frequently mentioned by HCPs in the reviewed articles. In this review, factors related to "CCSs' self-management skills, including knowledge”, the setting of LTFU care ("pediatric setting” or "adult setting"), "communication", and "structural circumstances" were identified as key factors for successful transition. CCSs' knowledge deficits related to cancer history, risk of late effects and importance of LTFU care were identified as major barriers that were mentioned by CCSs themselves and by HCPs. In addition, adult HCPs' lack of knowledge regarding late effects and caring for CCSs was also mentioned repeatedly as a barrier. The finding on the importance of the knowledge and education of CCSs and 
HCPs about transition is in accordance with that of other reviews assessing adolescents with other chronic

\subsection{Cultural and country-specific differences}

Transition practices are not uniform across the globe. Transitional care depends upon the possibilities of each country's health care system. In many studies from the US, one major barrier to transition was a lack of health insurance. In contrast to the US, where health insurance is often dependent on employment, Canada and many European countries have compulsory health insurance. Countries also differ to a great extent in the distribution of and distance to health care facilities, which might also affect the transition models used and the willingness of CCSs to attend LTFU care. In larger countries, shared-care models with the involvement of primary care physicians might be more convenient. In smaller countries, one or more centralized LTFU clinics can easily be reached by CCSs. This model of centralized LTFU care was presented in the Slovenian study by Jereb et al. [17] as a successful example. Acceptance of travel distances seems to be variable. The study by Granek et al. reported the use of transition and LTFU care models in Ontario with centralized LTFU clinics, and the survivors seemed to accept long travel distances [13]. All studies included in this review were conducted in first-world countries. The implementation of transition and LTFU care for CCSs in countries with limited resources needs to be investigated in the future. In addition to structures established by the state, such as health insurance, HCPs 
need to take the cultural background of the survivor and his or her family into account, as it might also affect the

\subsection{Transition tools}

Transition tools can be a helpful additional element in the preparation of CCSs to transition. They can help to detect knowledge gaps, fears or uncertainties but also areas where the CCSs have their strength and resources. Through education to address knowledge gaps, psychological support to address fears, and reinforcement where strengths already exist, CCSs can be supported in their independence. Information on helpful resources and toolkits for transition of adolescents and young adults with chronic diseases for physicians and patients are also available online, but most of these tools are not specific for CCS. One site is "GotTransition" from the US [45], which provides information for young adults, parents and caregivers, and health care professionals. More focused on health care providers is the initiative from the American College of Physicians (ACP), which provides disease-specific toolkits (e.g. congenital heart disease or hemophilia) [46]. In other countries, specific guidelines are in preparation, such as the AWMF guideline for transition in Germany [47] or exist already, such as the NICE guideline in the UK [48]. In addition to these examples of overarching sources, there are many national, disease-specific transition programs, for example from the British Diabetic Association [49], programs linked to a specific clinic, such as for congenital heart defects in Bern [50] or links specifically for adolescents or young adults, as an example the page "la suite" from Paris [51].

\subsection{Main features of the ideal transition}

There is no uniform and ideal transition practice that fits each CCS and that can be applied similarly in every country. This review highlights several key features. The transition from pediatric- to adult-focused LTFU care should be individually adapted to the needs of each survivor. These needs and knowledge gaps can be identified by using transition tools. The transition should be a gradual process rather than a one-step change. Pediatric HCPs should start to prepare CCSs for transition well in advance and educate them on their cancer history, future risks and need for LTFU care. The transition process should be well structured and organized, ideally 
involving collaboration between the pediatric and adult HCPs. Finally, good communication between HCPs and survivors as well as between pediatric and adult HCPs is paramount to enable a smooth transfer.

\subsection{Strengths and limitations}

The key strength of this study lies in the thorough application of the systematic review methodology, including the performance of all steps of the review by two reviewers. The majority of included studies were qualitative studies, which led to small numbers of preselected CCSs. Therefore, the included studies might have been affected by participation and response bias. We assume that survivors who participated in these qualitative studies were generally more interested in LTFU care than those who did not participate. Therefore, we might have lacked the input of survivors who were less motivated in LTFU care and who were more at risk for loss to follow-up. Our review is limited by the lack of reporting on loss to follow-up, and therefore, a clear judgment on the performance of different transition practices is not possible.

\section{Conclusion}

Our systematic review highlights important aspects of the transition of CCSs from pediatric- to adult-focused LTFU care. To date, there is no single-best model of transitional care, and the current literature describing transition practices is limited and does not evaluate adherence to follow-up care as a surrogate marker of transition success. We showed that good knowledge, education, and communication among CCSs and HCPs are key facilitators to transition that must be integrated into transition practices and tailored to the individual needs of each survivor and the framework of each country’s health care system.

\section{Conflict of interest statement}

None declared.

\section{References}

1. Oeffinger, K.C., et al., Chronic health conditions in adult survivors of childhood cancer. N Engl J Med, 2006. 355(15): p. 1572-82.

2. Geenen, M.M., et al., Medical assessment of adverse health outcomes in long-term survivors of childhood cancer. Jama, 2007. 297(24): p. 2705-15.

3. Rebholz, C.E., et al., Follow-up care amongst long-term childhood cancer survivors: a report from the Swiss Childhood Cancer Survivor Study. Eur J Cancer, 2011. 47(2): p. 221-9.

4. Rokitka, D.A., et al., Patterns of Loss to Follow-Up Care Among Childhood Cancer Survivors. J Adolesc Young Adult Oncol, 2017. 6(1): p. 67-73. 
5. Freyer, D.R., Transition of care for young adult survivors of childhood and adolescent cancer: rationale and approaches. J Clin Oncol, 2010. 28(32): p. 4810-8.

6. Blum, R.W., et al., Transition from child-centered to adult health-care systems for adolescents with chronic conditions. A position paper of the Society for Adolescent Medicine. J Adolesc Health, 1993. 14(7): p. 570-6.

7. Friedman, D.L., D.R. Freyer, and G.A. Levitt, Models of care for survivors of childhood cancer. Pediatr Blood Cancer, 2006. 46(2): p. 159-68.

8. Oeffinger, K.C. and M.S. McCabe, Models for delivering survivorship care. J Clin Oncol, 2006. 24(32): p. 5117-24.

9. Singer, S., et al., General practitioner involvement in follow-up of childhood cancer survivors: a systematic review. Pediatr Blood Cancer, 2013. 60(10): p. 1565-73.

10. Eshelman-Kent, D., et al., Cancer survivorship practices, services, and delivery: a report from the Children's Oncology Group (COG) nursing discipline, adolescent/young adult, and late effects committees. J Cancer Surviv, 2011. 5(4): p. 345-57.

11. Liberati, A., et al., The PRISMA statement for reporting systematic reviews and metaanalyses of studies that evaluate health care interventions: explanation and elaboration. PLoS Med, 2009. 6(7): p. e1000100.

12. Joanna, B. Critical Appraisal Tools. Accessed 26 April 2020. Available from: https://joannabriggs.org/ebp/critical_appraisal_tools.

13. Granek, L., et al., Psychological factors impacting transition from paediatric to adult care by childhood cancer survivors. J Cancer Surviv, 2012. 6(3): p. 260-9.

14. Blaauwbroek, R., et al., Shared care by paediatric oncologists and family doctors for longterm follow-up of adult childhood cancer survivors: a pilot study. Lancet Oncol, 2008. 9(3): p. 232-8.

15. Berger, C., et al., Long-Term Follow-up Consultation After Childhood Cancer in the RhoneAlpes Region of France: Feedback From Adult Survivors and Their General Practitioners. J Adolesc Young Adult Oncol, 2017. 6(4): p. 524-534.

16. Costello, A.G., et al., Shared Care of Childhood Cancer Survivors: A Telemedicine Feasibility Study. J Adolesc Young Adult Oncol, 2017. 6(4): p. 535-541.

17. Jereb, B., Model for long-term follow-up of survivors of childhood cancer. Med Pediatr Oncol, 2000. 34(4): p. 256-8.

18. McClellan, W., et al., A Collaborative Step-Wise Process to Implementing an Innovative Clinic for Adult Survivors of Childhood Cancer. J Pediatr Nurs, 2015. 30(5): p. e147-55.

19. Bashore, L. and J. Bender, Evaluation of the Utility of a Transition Workbook in Preparing Adolescent and Young Adult Cancer Survivors for Transition to Adult Services: A Pilot Study. J Pediatr Oncol Nurs, 2016. 33(2): p. 111-8.

20. Klassen, A.F., et al., The development of scales to measure childhood cancer survivors' readiness for transition to long-term follow-up care as adults. Health Expect, 2015. 18(6): p. 1941-55.

21. Schwartz, L.A., et al., Stakeholder validation of a model of readiness for transition to adult care. JAMA Pediatr, 2013. 167(10): p. 939-46.

22. Schwartz, L.A., et al., Development and Content Validation of the Transition Readiness Inventory Item Pool for Adolescent and Young Adult Survivors of Childhood Cancer. J Pediatr Psychol, 2017. 42(9): p. 983-994.

23. Schwartz, L.A., et al., A social-ecological model of readiness for transition to adult-oriented care for adolescents and young adults with chronic health conditions. Child Care Health Dev, 2011. 37(6): p. 883-95.

24. Klassen, A.F., et al., Development and validation of a generic scale for use in transition programmes to measure self-management skills in adolescents with chronic health conditions: the TRANSITION-Q. Child Care Health Dev, 2015. 41(4): p. 547-58. 
25. Frederick, N.N., et al., Preparing childhood cancer survivors for transition to adult care: The young adult perspective. Pediatr Blood Cancer, 2017. 64(10).

26. Quillen, J., H. Bradley, and C. Calamaro, Identifying Barriers Among Childhood Cancer Survivors Transitioning to Adult Health Care. J Pediatr Oncol Nurs, 2017. 34(1): p. 20-27.

27. Rosenberg-Yunger, Z.R., et al., Barriers and Facilitators of Transition from Pediatric to Adult Long-Term Follow-Up Care in Childhood Cancer Survivors. J Adolesc Young Adult Oncol, 2013. 2(3): p. 104-11.

28. Sadak, K.T., A. Dinofia, and G. Reaman, Patient-perceived facilitators in the transition of care for young adult survivors of childhood cancer. Pediatr Blood Cancer, 2013. 60(8): p. 1365-8.

29. Szalda, D., et al., Associates of Engagement in Adult-Oriented Follow-Up Care for Childhood Cancer Survivors. J Adolesc Health, 2017. 60(2): p. 147-153.

30. van Laar, M., et al., The impact of a managed transition of care upon psychosocial characteristics and patient satisfaction in a cohort of adult survivors of childhood cancer. Psychooncology, 2013. 22(9): p. 2039-45.

31. Kenney, L.B., et al., Transition and transfer of childhood cancer survivors to adult care: $A$ national survey of pediatric oncologists. Pediatr Blood Cancer, 2017. 64(2): p. 346-352.

32. Mouw, M.S., et al., Care Transitions in Childhood Cancer Survivorship: Providers' Perspectives. J Adolesc Young Adult Oncol, 2017. 6(1): p. 111-119.

33. Sadak, K.T., et al., Identifying metrics of success for transitional care practices in childhood cancer survivorship: A qualitative study of survivorship providers. Pediatr Blood Cancer, 2017. 64(11).

34. Sadak, K.T., et al., Transitional care practices, services, and delivery in childhood cancer survivor programs: A survey study of U.S. survivorship providers. Pediatr Blood Cancer, 2019. 66(8): p. e27793.

35. Signorelli, C., et al., Models of childhood cancer survivorship care in Australia and New Zealand: Strengths and challenges. Asia Pac J Clin Oncol, 2017. 13(6): p. 407-415.

36. Casillas, J., et al., Transitioning childhood cancer survivors to adult-centered healthcare: insights from parents, adolescent, and young adult survivors. Psychooncology, 2010. 19(9): p. 982-90.

37. Nandakumar, B.S., et al., Attitudes and experiences of childhood cancer survivors transitioning from pediatric care to adult care. Support Care Cancer, 2018. 26(8): p. 27432750.

38. McCann, L., N. Kearney, and Y. Wengstrom, "It's just going to a new hospital ... that's it. "Or is it? An experiential perspective on moving from pediatric to adult cancer services. Cancer Nurs, 2014. 37(5): p. E23-31.

39. Afzali, A. and G. Wahbeh, Transition of pediatric to adult care in inflammatory bowel disease: Is it as easy as 1, 2, 3? World J Gastroenterol, 2017. 23(20): p. 3624-3631.

40. Cadario, F., et al., Transition process of patients with type 1 diabetes (T1DM) from paediatric to the adult health care service: a hospital-based approach. Clin Endocrinol (Oxf), 2009. 71(3): p. 346-50.

41. Buschur, E.O., B. Glick, and M.K. Kamboj, Transition of care for patients with type 1 diabetes mellitus from pediatric to adult health care systems. Transl Pediatr, 2017. 6(4): p. 373-382.

42. Sabbagh, S., T. Ronis, and P.H. White, Pediatric rheumatology: addressing the transition to adult-orientated health care. Open Access Rheumatol, 2018. 10: p. 83-95.

43. Lugasi, T., M. Achille, and M. Stevenson, Patients' perspective on factors that facilitate transition from child-centered to adult-centered health care: a theory integrated metasummary of quantitative and qualitative studies. J Adolesc Health, 2011. 48(5): p. 42940.

44. Crowley, R., et al., Improving the transition between paediatric and adult healthcare: $a$ systematic review. Arch Dis Child, 2011. 96(6): p. 548-53. 
45. The National Alliance to Advance Adolescent Health. GotTransition. Accessed 08 July 2020. Available from: https://www.gottransition.org/index.cfm.

46. American College of Physicians (ACP). Pediatric to Adult Care Transitions Initiative. Accessed 08 July 2020. Available from: https://www.acponline.org/clinical-information/high-valuecare/resources-for-clinicians/pediatric-to-adult-care-transitions-initiative.

47. Arbeitsgemeinschaft der Wissenschaftlichen Medizinischen Fachgesellschaften (AWMF). Transition von der Pädiatrie in die Erwachsenenmedizin. Accessed 08 July 2020. Available from: https://www.awmf.org/leitlinien/detail/anmeldung/1/ll/186-001.html.

48. National Institute for Health and care Excellence (NICE). Transition from children's to adults' services for young people using health or social care services. Accessed 08 July 2020. Available from: https://www.nice.org.uk/guidance/ng43.

49. The British Diabetic Association. Transition of young people with diabetes from paediatric care to adult care (our position) Accessed 08 July 2020. Available from: https://www.diabetes.org.uk/professionals/position-statements-reports/diagnosis-ongoingmanagement-monitoring/transition.

50. Inselspital. Zentrum für angeborene Herzfehler - Übergang auf die GUCH. Accessed 08 July 2020. Available from: http://www.ang-herzfehler.ch/de/fuer-jugendliche-new/uebergangauf-die-guch/.

51. Assistance Hôpitaux Publique de Paris. La Suite. Accessed 08 July 2020. Available from: http://www.la-suite-necker.aphp.fr/hello/\#_la-suite. 
Table 1: Summary of studies describing transition processes $(n=6)$

\begin{tabular}{|c|c|}
\hline $\begin{array}{l}\text { First Author, } \\
\text { Year, Country }\end{array}$ & \\
\hline $\begin{array}{l}\text { Berger, 2017, } \\
\text { France [15] }\end{array}$ & $\begin{array}{l}\text { Shared-care model } \\
\text { - SALTO consultation: joint consultation with a pediatric oncologist and internist in } \\
\text { addition to general practitioner follow-up care }\end{array}$ \\
\hline $\begin{array}{l}\text { Blaauwbroek, } \\
2008 \text {, } \\
\text { Netherlands } \\
{[14]}\end{array}$ & $\begin{array}{l}\text { Shared-care model } \\
\text { - collaboration of pediatric oncologist and on-site family doctor at LTFU clinic at the } \\
\text { University Medical Centre Groningen with local family doctor } \\
\text { - collaboration with other specialists as needed }\end{array}$ \\
\hline $\begin{array}{l}\text { Costello, 2017, } \\
\text { USA [16] }\end{array}$ & $\begin{array}{l}\text { Shared-care model } \\
\text { - collaboration of pediatric oncologist and primary care provider } \\
\text { - joint consultation using telemedicine }\end{array}$ \\
\hline $\begin{array}{l}\text { Granek, 2012, } \\
\text { Canada [13] }\end{array}$ & $\begin{array}{l}\text { Pediatric and adult LTFU care provided in a common clinic } \\
\text { - specialized LTFU clinic for pediatric and adult CCS } \\
\text { - multidisciplinary team } \\
\text { - referral to specialists as needed } \\
\text { Transition to adult LTFU clinic } \\
\text { - transition at age } 18 \\
\text { - specialized LTFU clinic for adult CCS } \\
\text { - multidisciplinary team } \\
\text { - referral to specialists as needed }\end{array}$ \\
\hline $\begin{array}{l}\text { Jereb, 2000, } \\
\text { Slovenia [17] }\end{array}$ & $\begin{array}{l}\text { Transition to adolescent/adult LTFU clinic } \\
\text { - transition at age } 16 \\
\text { - multidisciplinary team lead by adult oncologist } \\
\text { - collaboration with specialists as needed } \\
\text { - monthly meetings for survivors offered }\end{array}$ \\
\hline $\begin{array}{l}\text { McClellan, } \\
\text { 2015, USA [18] }\end{array}$ & $\begin{array}{l}\text { Survivorship transition clinic } \\
\text { - transition from pediatric LTFU clinic to specialized LTFU clinic within an outpatient } \\
\text { Internal Medicine Clinic } \\
\text { - transition nurse navigator } \\
\text { - multidisciplinary team } \\
\text { - possibility for shared-care with primary care physician } \\
\text { - referral to subspecialists as needed }\end{array}$ \\
\hline
\end{tabular}


Table 2: Summary of studies describing transition tools $(n=5)$

\begin{tabular}{|l|l|}
\hline $\begin{array}{l}\text { First Author, } \\
\text { Year, Country }\end{array}$ & \\
\hline $\begin{array}{l}\text { Bashore, 2016, } \\
\text { USA [19] }\end{array}$ & $\begin{array}{l}\text { Transition workbook } \\
\text { - method of preparing survivors to transition to adult care }\end{array}$ \\
\hline $\begin{array}{l}\text { Klassen, 2014, } \\
\text { Canada [20] }\end{array}$ & $\begin{array}{l}\text { Transition scales } \\
\text { - development and evaluation of cancer worry scale, self-management skills scale, } \\
\text { expectations scale }\end{array}$ \\
\hline $\begin{array}{l}\text { Klassen, 2014, } \\
\text { Canada [24] }\end{array}$ & $\begin{array}{l}\text { Transition-Q } \\
\text { - development and validation of self-management skill scale for adolescents with chronic } \\
\text { health conditions (further development of scale developed for childhood cancer patients) }\end{array}$ \\
\hline $\begin{array}{l}\text { Schwartz, 2011, } \\
\text { USA [22] }\end{array}$ & $\begin{array}{l}\text { SMART } \\
\text { - development of SMART model } \\
\text { - social-ecological model of readiness for transition to adult-oriented care for adolescents } \\
\text { and adults with chronic health conditions }\end{array}$ \\
\hline $\begin{array}{l}\text { Schwartz, 2013, } \\
\text { USA [21] }\end{array}$ & $\begin{array}{l}\text { SMART } \\
\text { - further validate SMART for survivors of childhood cancer }\end{array}$ \\
\hline $\begin{array}{l}\text { Schwartz, 2017, } \\
\text { USA [23] }\end{array}$ & $\begin{array}{l}\text { Transition Readiness Inventory (TRI) Item Pool } \\
\text { - development and validation of TRI Item Pool based on SMART }\end{array}$ \\
\hline
\end{tabular}


Table 3: Characteristics of studies reporting on barriers and facilitators in the context of childhood cancer survivors' transition from pediatric to adult long-term follow-up care

\begin{tabular}{|c|c|c|c|c|c|c|c|}
\hline $\begin{array}{l}\text { First Author, } \\
\text { Year, Country }\end{array}$ & Study design & Sample size & $\begin{array}{l}\text { Age at } \\
\text { diagnosis } \\
\text { [years] }\end{array}$ & $\begin{array}{l}\text { Age at study } \\
\text { [years] }\end{array}$ & $\begin{array}{l}\text { Time point of } \\
\text { transition at study }\end{array}$ & Type of transition & $\begin{array}{l}\text { Quality } \\
\text { Assessment }\end{array}$ \\
\hline $\begin{array}{l}\text { Casillas, 2010, } \\
\text { USA [36] }\end{array}$ & $\begin{array}{l}\text { Qualitative, } \\
\text { interview with } \\
\text { survivors, focus } \\
\text { group with } \\
\text { parents }\end{array}$ & $\begin{array}{l}\text { Survivors: } \mathrm{n}=27 \\
\text { Parents: } \mathrm{n}=21\end{array}$ & $\begin{array}{l}\text { Mean } 12 \\
\text { (range 2-18) }\end{array}$ & $\begin{array}{l}\text { Mean } 20 \\
\text { (range 15-39) }\end{array}$ & Not mentioned & $\begin{array}{l}\text { To adult care (not further } \\
\text { specified) }\end{array}$ & QR: Quality 2 \\
\hline $\begin{array}{l}\text { Frederick, 2017, } \\
\text { USA [25] }\end{array}$ & $\begin{array}{l}\text { Qualitative, } \\
\text { semi-structured } \\
\text { focus groups }\end{array}$ & Survivor: $\mathrm{n}=16$ & $\begin{array}{l}\text { Mean 8.6 } \\
\text { (range 1-17) }\end{array}$ & $\begin{array}{l}\text { Mean } 27.5 \\
\text { (range } 22-39 \text { ) }\end{array}$ & $\begin{array}{l}\text { Before and after } \\
\text { transition }\end{array}$ & Not mentioned & QR: Quality 2 \\
\hline $\begin{array}{l}\text { Granek, 2012, } \\
\text { Canada [13] }\end{array}$ & $\begin{array}{l}\text { Qualitative, } \\
\text { semi-structured } \\
\text { interview }\end{array}$ & Survivors: $\mathrm{n}=38$ & Range $0-17$ & Range $15-26$ & $\begin{array}{l}\text { Pre-transition }(n=10), \\
\text { successful transition } \\
(n=11), \text { failed transition } \\
(n=7), \text { dropped out of } \\
\text { transition }(n=10)\end{array}$ & $\begin{array}{l}\text { - Pediatric LTFU clinic } \\
\text { to adult LTFU clinic } \\
\text { - Remaining in same } \\
\text { LTFU clinic }\end{array}$ & QR: Quality 2 \\
\hline $\begin{array}{l}\text { Kenney, 2017, } \\
\text { USA [31] }\end{array}$ & $\begin{array}{l}\text { Observational, } \\
\text { cross-sectional, } \\
\text { survey }\end{array}$ & $\begin{array}{l}\mathrm{HCP}(\mathrm{COG} \\
\text { members): } \\
\mathrm{n}=347\end{array}$ & NA & NA & NA & Not mentioned & CS: Quality 2 \\
\hline $\begin{array}{l}\text { McCann, 2014, } \\
\text { Scotland [38] }\end{array}$ & $\begin{array}{l}\text { Qualitative, } \\
\text { semi-structured } \\
\text { interview }\end{array}$ & $\begin{array}{l}\text { Dyads survivors/ } \\
\text { parents: } n=12 \\
\text { HCP: } n=11\end{array}$ & Range $1-11$ & Range $17-25$ & $\begin{array}{l}\mathrm{n}=6 \text { dyads before } \\
\text { transition } \\
\mathrm{n}=6 \text { dyads after } \\
\text { transition }\end{array}$ & $\begin{array}{l}\text { To adult care (not further } \\
\text { specified) }\end{array}$ & QR: Quality 2 \\
\hline $\begin{array}{l}\text { Mouw, 2017, } \\
\text { USA [32] }\end{array}$ & $\begin{array}{l}\text { Qualitative, } \\
\text { semi-structured } \\
\text { interview }\end{array}$ & $\begin{array}{l}\mathrm{HCP}(\mathrm{COG} \\
\text { affiliated } \\
\text { institutions) } \mathrm{n}=20\end{array}$ & NA & NA & NA & Not mentioned & QR: Quality 3 \\
\hline $\begin{array}{l}\text { Nandakumar, } \\
2018, \\
\text { Australia and } \\
\text { New Zealand [37] }\end{array}$ & $\begin{array}{l}\text { Qualitative, } \\
\text { semi-structured } \\
\text { telephone } \\
\text { interview } \\
\end{array}$ & $\begin{array}{l}\text { Parents: } \mathrm{n}=15 \\
\text { Survivor: } \mathrm{n}=18\end{array}$ & $\begin{array}{l}\text { Parents: Mean } \\
2.5 \text { (SD 1.6) } \\
\text { Survivors: Mean } \\
6.8 \text { (SD 5.1) } \\
\end{array}$ & $\begin{array}{l}\text { Parents: Mean } 15 \\
\text { (SD 1.9) } \\
\text { Survivors: Mean } \\
26 \text { (SD 6.3) } \\
\end{array}$ & $\begin{array}{l}\text { Parents: } \mathrm{n}=4 \text { after } \\
\text { transition } \\
\text { Survivors: } \mathrm{n}=11 \text { after } \\
\text { transition }\end{array}$ & $\begin{array}{l}\text { To primary care provider } \\
(\mathrm{n}=15)\end{array}$ & QR: Quality 2 \\
\hline $\begin{array}{l}\text { Quillen, 2017, } \\
\text { USA [26] }\end{array}$ & $\begin{array}{l}\text { Observational, } \\
\text { cross-sectional, } \\
\text { survey }\end{array}$ & Survivors: $\mathrm{n}=48$ & $<21$ years & $\begin{array}{l}\text { Mean 23.3 (range } \\
20-25)\end{array}$ & $\begin{array}{l}\text { All transitioned to adult } \\
\text { facility }\end{array}$ & $\begin{array}{l}\text { Adult oncologist, adult } \\
\text { primary care provider }\end{array}$ & CS: Quality 1 \\
\hline
\end{tabular}




\begin{tabular}{|c|c|c|c|c|c|c|c|}
\hline $\begin{array}{l}\text { Rosenberg- } \\
\text { Yunger, 2013, } \\
\text { Canada [27] }\end{array}$ & $\begin{array}{l}\text { Qualitative } \\
\text { Semi-structured } \\
\text { interview }\end{array}$ & Survivors: $\mathrm{n}=38$ & Range $0-18$ & Range $16-26$ & $\begin{array}{l}\text { Pre-transition }(n=10), \\
\text { successful transition } \\
(n=11), \text { failed transition } \\
(n=7), \text { dropped out of } \\
\text { transition }(n=10)\end{array}$ & $\begin{array}{l}\text { - Pediatric LTFU clinic } \\
\text { to adult LTFU clinic } \\
\text { - Remaining in same } \\
\text { LTFU clinic }\end{array}$ & QR: Quality 2 \\
\hline $\begin{array}{l}\text { Sadak 2013, USA } \\
\text { [28] }\end{array}$ & $\begin{array}{l}\text { Cross-sectional } \\
\text { survey }\end{array}$ & Survivors: $n=103$ & $\mathrm{NA}$ & $16->35$ & All before transition & $\mathrm{NA}$ & CS: Quality 1 \\
\hline $\begin{array}{l}\text { Sadak, 2017, } \\
\text { USA [33] }\end{array}$ & $\begin{array}{l}\text { Qualitative, } \\
\text { semi-structured } \\
\text { telephone } \\
\text { interview }\end{array}$ & $\begin{array}{l}\text { HCP: } \mathrm{n}=29 \\
\text { (key informants } \\
\text { involved in } \\
\text { transition) }\end{array}$ & $\mathrm{NA}$ & NA & NA & $\begin{array}{l}\text { Three cancer center } \\
\text { including pediatric and } \\
\text { adult facilities }\end{array}$ & QR: Quality 2 \\
\hline $\begin{array}{l}\text { Sadak, 2019, } \\
\text { USA [34] }\end{array}$ & $\begin{array}{l}\text { Cross-sectional } \\
\text { survey }\end{array}$ & $\begin{array}{l}\text { COG members: } \\
\mathrm{n}=97\end{array}$ & NA & NA & NA & $\begin{array}{l}\text { - Adult-centered care in } \\
\text { pediatric cancer clinic } \\
\text { - Adult cancer clinic } \\
\text { - Pediatric/adult non- } \\
\text { cancer clinic } \\
\text { - Adolescent and young } \\
\text { adult cancer clinic }\end{array}$ & CS: Quality 2 \\
\hline $\begin{array}{l}\text { Signorelli, 2017, } \\
\text { Australia and } \\
\text { New Zealand [35] }\end{array}$ & $\begin{array}{l}\text { Qualitative, } \\
\text { semi-structured } \\
\text { telephone } \\
\text { interview }\end{array}$ & HCP: $n=19$ & $\mathrm{NA}$ & $\mathrm{NA}$ & NA & $\begin{array}{l}\text { Different between } \\
\text { clinics, risk-based, some } \\
\text { to general practitioner }\end{array}$ & QR: Quality 2 \\
\hline $\begin{array}{l}\text { Szalda, 2017, } \\
\text { USA [29] }\end{array}$ & $\begin{array}{l}\text { Observational, } \\
\text { cross-sectional, } \\
\text { survey }\end{array}$ & Survivors: $\mathrm{n}=80$ & $\begin{array}{l}\text { Mean 10.4 } \\
\text { (range 0.5-22) }\end{array}$ & $\begin{array}{l}\text { Mean } 27.7 \text { (range } \\
23-36 \text { ) }\end{array}$ & After transition & $\begin{array}{l}\text { From children's hospital } \\
\text { to adult care/ provider }\end{array}$ & CS: Quality 1 \\
\hline $\begin{array}{l}\text { Van Laar, 2013, } \\
\text { UK [30] }\end{array}$ & $\begin{array}{l}\text { Observational, } \\
\text { cross-sectional, } \\
\text { survey }\end{array}$ & Survivors: $n=143$ & $\begin{array}{l}\text { Pediatric: } \\
\text { Median 9 (IQR } \\
\text { 5.7-12.9) } \\
\text { Adult: Median } \\
\text { 10.2 (IQR 4.5- } \\
\text { 13.4) }\end{array}$ & $\begin{array}{l}\text { Pediatric: Median } \\
24 \text { (IQR 21-27) } \\
\text { Adult: Median } 24 \\
(21.7 \text { - 32) }\end{array}$ & $\begin{array}{l}\text { Pediatric setting: } n=69 \\
\text { Adult setting: } n=74\end{array}$ & $\begin{array}{l}\text { From children's hospital } \\
\text { to adult cancer center } \\
\text { (trained in pediatrics and } \\
\text { adult medicine) }\end{array}$ & CS: Quality 2 \\
\hline
\end{tabular}

CS, cross-sectional study; GP, general practitioner; HCP, health care professionals; LTFU, lung-term follow-up; NA, not applicable; QR, qualitative research; SD, standard deviation 
Table 4: Summary of barriers and facilitators reported in the eligible studies $(n=15)$

\begin{tabular}{|c|c|}
\hline \multicolumn{2}{|l|}{ Barriers } \\
\hline $\begin{array}{l}\text { CCS' self-management skills, } \\
\text { including knowledge and } \\
\text { empowerment }\end{array}$ & $\begin{array}{l}\text { - CCS knowledge deficits or incorrect information on: } \\
\text { - disease and treatment history [25] } \\
\text { - long-term complications [25] } \\
\text { - importance of health care screening / LTFU care [26, 27, 32] } \\
\text { - navigation of the adult medical system [25] } \\
\text { - preventive and healthy lifestyle [32] } \\
\text { - CCS cognitive delay / impaired development [31, 32, 37] } \\
\text { - Knowing that cancer had a good prognosis for survival, minimal rates } \\
\text { of relapse and late effects [27] }\end{array}$ \\
\hline $\begin{array}{l}\text { Social environment, including } \\
\text { family, friends, and peers }\end{array}$ & $\begin{array}{l}\text { - Parental factors } \\
\text { - conversations about risks for late effects is avoided by parents [36] } \\
\text { - anxiety, loss of control, fear of the unknown hinder independence of } \\
\text { their child and change from doctor-patient-parent triad to doctor- } \\
\text { patient dyad }[25,33,36] \\
\text { - Cancer seen as contagious and incurable illness, leading to } \\
\text { stigmatization } 36] \\
\text { - Unstable social situation [31] } \\
\text { - CCS living further away from the clinic }[27,32]\end{array}$ \\
\hline $\begin{array}{l}\text { CCS' personal feelings and } \\
\text { emotions }\end{array}$ & $\begin{array}{l}\text { - "Cancer a thing of the past" [13] } \\
\text { - Medical transition coincide with other changes in life [38] } \\
\text { - Believing there is no point to attend LTFU [27] } \\
\text { - Not willing to take time to attend LTFU [27] } \\
\text { - Believing LTFU appointments are redundant [27] } \\
\text { - Having no late effects and concerns about health [27] } \\
\text { - Hearing only good news at appointments [27] } \\
\text { - Fear/ anxiety of relapse, new cancer, late effects, of dying of cancer, } \\
\text { and fearful memories [13,27] }\end{array}$ \\
\hline $\begin{array}{l}\text { Pediatric setting, including CCSs } \\
\text { perception }\end{array}$ & $\begin{array}{l}\text { - Attachment of patient/parent to provider and vice versa and concerns } \\
\text { about terminating the relationship }[27,31,34,37] \\
\text { - Unstable medical condition in CCS [31] } \\
\text { - Survivors not ready for adult-centered care from a psychosocial or } \\
\text { medical standpoint [34] }\end{array}$ \\
\hline $\begin{array}{l}\text { Adult setting, including CCSs } \\
\text { perception }\end{array}$ & $\begin{array}{l}\text { - (Lack of) adult providers familiar/ comfortable with CCS and SCP } \\
\text { [25, 31, 32, 34, 35] } \\
\text { - Adult models of care cannot accommodate influx of new patients [34] } \\
\text { - Concerns of pediatric oncologists that adult providers' lack knowledge } \\
\text { to care for CCS [31, 32] } \\
\text { - Concerns of CCS that new providers do not understand healthcare } \\
\text { needs [27] } \\
\text { - Environment in adult hospital } \\
\text { - perceived as rushed and impersonal by CCS [27, 37] } \\
\text { - makes CCS think about cancer and death [27] } \\
\text { - perceived harder to navigate for CCS and families [32] }\end{array}$ \\
\hline Financial issues and insurance & $\begin{array}{l}\text { - Health insurance issues }[31,32,34] \\
\text { - Financial barriers, medical costs }[26,31]\end{array}$ \\
\hline Communication & $\begin{array}{l}\text { - Inadequate communication between CCS, pediatric and adult HCP } \\
\text { [37] } \\
\text { - Miscommunication about LTFU care [27] }\end{array}$ \\
\hline $\begin{array}{l}\text { Structural circumstances, } \\
\text { including organization of } \\
\text { transition }\end{array}$ & $\begin{array}{l}\text { - CCS have little/ no information about adult hospital before transfer } \\
\text { [38] } \\
\text { - CCS experience difficulties to organize or reschedule appointments at } \\
\text { adult provider }[26,27] \\
\text { - Lack of coordination between multiple appointments [27] } \\
\text { - Undefined transition process [35] }\end{array}$ \\
\hline \multicolumn{2}{|l|}{ Facilitators } \\
\hline $\begin{array}{l}\text { CCS' self-management skills, } \\
\text { including knowledge and } \\
\text { empowerment }\end{array}$ & $\begin{array}{l}\text { - CCS knowledge on: } \\
\text { - disease and treatment history [32] } \\
\text { - long-term complications/ risk for late effects }[25,26,32]\end{array}$ \\
\hline
\end{tabular}




\begin{tabular}{|c|c|}
\hline & $\begin{array}{l}\text { - importance of health care screening / LTFU care also in adulthood } \\
\quad[25,26,27,30,33,38] \\
\text { - preventive and health lifestyle [32] } \\
\text { - Adequate, appropriate, and early information [37] } \\
\text { - Empowerment of CCS for independence and self-management skills } \\
\text { [25, 26, 32, 35, 37] } \\
\text { - CCS being able to advocate for themselves and navigate in health care } \\
\text { system [32] } \\
\text { - Ageing / getting older [37] }\end{array}$ \\
\hline $\begin{array}{l}\text { Social environment, including } \\
\text { family, friends, and peers }\end{array}$ & $\begin{array}{l}\text { - Parental/family factors } \\
\text { - Involvement of parents/ family in health care decision-making and } \\
\text { survivorship care }[29,36] \\
\text { - Parental worry [27] } \\
\text { - Parents/family offering practical support (e.g. transportation to } \\
\text { appointments [27]) } \\
\text { - Parent/ family member for moral support at appointment [27] } \\
\text { - Talking about importance of LTFU care / spending time with Friends } \\
\text { and peers [27] }\end{array}$ \\
\hline $\begin{array}{l}\text { CCS' personal feelings and } \\
\text { emotions }\end{array}$ & $\begin{array}{l}\text { - Identification as "cancer survivor" [13] } \\
\text { - Going to LTFU care to ensure health [27] } \\
\text { - Having concern with health or cancer worries }[13,27] \\
\text { - Having symptoms or late effects [27] } \\
\text { - Gratitude of being alive, sense of responsibility to attend follow-up } \\
\text { care, help others by participating in research through attending LTFU } \\
{[13,27]}\end{array}$ \\
\hline Pediatric setting & No study \\
\hline $\begin{array}{l}\text { Adult setting, including CCSs } \\
\text { perception }\end{array}$ & $\begin{array}{l}\text { - Good/ familiar relationship between HCP and CCS/ families [27, 32] } \\
\text { - Confidence in physician who understands burden of late effects, } \\
\text { needs for comprehensive care, and includes subspecialists [27, 28, 37] } \\
\text { - Having a familiar and friendly adult environment [27] }\end{array}$ \\
\hline Financial issues and insurance & $\begin{array}{l}\text { - Having health insurance }[28,29] \\
\text { - Opportunity to get insurance counseling [28] }\end{array}$ \\
\hline Communication & $\begin{array}{l}\text { - Clear and developmentally appropriate communication between } \\
\text { CCS/families and provider }[25,33,36] \\
\text { - Good communication among past and future HCP }[25,33,37] \\
\text { - Pediatric HCPs know PCPs [32] }\end{array}$ \\
\hline $\begin{array}{l}\text { Structural circumstances, } \\
\text { including organization of } \\
\text { transition }\end{array}$ & $\begin{array}{l}\text { - Transition } \\
\text { - Transition as a process and gradual transfer of care - planning, } \\
\text { preparation and flexible time point of transition are key elements } \\
\text { [25, 26, 31, 32, 38] } \\
\text { - Transition process start in early adolescence }[25,33] \\
\text { - Talk repeatedly about (time point of) transition with CCS and } \\
\text { parents [33, 38] } \\
\text { - Meet adult oncology team before leaving pediatric hospital [38] } \\
\text { - Appointment(s) } \\
\text { - Receiving help to find appropriate adult provider [25] } \\
\text { - Receiving next appointment at a scheduled visit, also when leaving } \\
\text { pediatric setting [26, 27] } \\
\text { - Receiving reminder calls about appointments [27] } \\
\text { - Flexibility when booking or rescheduling appointments [27, 28] } \\
\text { - Structural } \\
\text { - Shorter distance CCS - cancer center [32, 37] } \\
\text { - Provide specific information/ materials to CCS to be communicated } \\
\text { to new provider, e.g. survivorship care plan [25, 32] } \\
\text { - Coordinated appointments with multiple specialist [27, 28, 33] } \\
\text { - Patient navigator [28, 33] } \\
\text { - National or binational model of care [35] }\end{array}$ \\
\hline
\end{tabular}


Click here to access/download Supplementary material Transition_Review_Supplemental_Revision.docx 